lessened by some $80 \%$ within one day without any discernible adverse effects. Such an effect has received little attention. Dalby ${ }^{3}$ describes one case of rheumatic chorea which responded well and Swash et al make passing mention of the effectiveness of this treatment in a case of recurrent rheumatic chorea. Some have expressed reservations about tetrabenazine in Huntington's chorea, ${ }^{4}$ suggesting that the risks of depression and drug-induced Parkinsonism outweigh the advantages of its anti-choreic action. This viewpoint has not been universally accepted. ${ }^{125}$ Such unwanted effects would be more likely to develop during long-term treatment, but in Sydenham's chorea the movements seldom last in a severe form beyond three months, so side effects would be expected infrequently.

The authors would like to express their thanks to Dr L S Illis, Wessex Neurological Centre, Southampton, for permission to report the data in Case 1.

${ }^{1}$ McLellan, D L, Chalmers, R J, and Johnson, R H, Lancet, 1974, 1, 104. 2 Swash, M, et al, Journal of Neurology, Neurosurgery and Psychiatry, $1972,35,186$

${ }^{3}$ Dalby, M A, British Medical fournal, 1969, 2, 422.

4 Huang, C Y, et al, Medical fournal of Australia, 1976, 1, 583.

5 Thavasothy, R, British Medical fournal, 1970, 2, 237.

\section{Familial autoimmune haemolytic anaemia}

Familial autoimmune haemolytic anaemia (AIHA) has rarely been reported in man. ${ }^{1-3}$ We describe two sisters who developed the disorder at the same age; one responded partially to low-dose prednisolone, while the other required splenectomy. HLA typing of these patients and of three siblings provided supportive evidence for an association between HLA-1 and 8 and AIHA. ${ }^{4}$

\section{Present series}

Case 1-A 66-year-old woman of previous good health presented in 1970 with a four-month history of dyspnoea, palpitations, peripheral oedema, and increasing weakness. She was icteric and pale with an enlarged liver and spleen ( 3 and $5 \mathrm{~cm}$ respectively below the costal margin). Haemoglobin was $6.4 \mathrm{~g} / \mathrm{dl}$; WBC $4 \times 10^{9} / 1\left(4000 / \mathrm{mm}^{3}\right)$; and reticulocyte count $35 \%$. The peripheral blood film contained spherocytes, and a marrow aspirate showed normoblastic hyperplasia. Serum bilirubin concentration was $52 \mu \mathrm{mol} / 1$ $(3 \mathrm{mg} / 100 \mathrm{ml}$ ) (normal $2-17 \mu \mathrm{mol} / 1 ; 0 \cdot 1-1 \cdot 0 \mathrm{mg} / 100 \mathrm{ml}$ ), and, though result of the antinuclear factor (ANF) test was positive, LE cell preparations were negative. Autologous erythrocyte survival was 11.5 days (normal 25-35), with a spleen to liver ratio of 4:1. The direct antiglobulin test (DAGT) result was positive (table). There were no intracorpuscular redcell abnormalities, and no evidence of intravascular haemolysis was found. By mistake she was given only $4 \mathrm{mg}$ prednisolone daily instead of the usual $40-60 \mathrm{mg}$ but made a slow partial recovery, which was probably spontaneous. In view of her clinical improvement together with a fall in the DAGT titre and disappearance of free serum antibodies it was decided to continue that dosage of prednisolone indefinitely. She remained clinically well despite an $11.5^{\circ}$ reticulocytosis and a DAGT titre of 140 . The most recent haemoglobin was $13.5 \mathrm{~g} / \mathrm{dl}$ and the serum bilirubin $35 \mu \mathrm{mol} /(2 \mathrm{mg} / 100 \mathrm{ml})$.

Case 2-This patient, a 64-year-old full sister of case 1, presented in 1975 with a two-year history of increasing dyspnoea and fatigue. She was pale and icteric and her spleen and liver were enlarged 8 and $3 \mathrm{~cm}$ respectively below the costal margin. Haemoglobin was $6.1 \mathrm{~g} / \mathrm{dl}$; WBC $4.9 \because 10^{9} / 1\left(4900 / \mathrm{mm}^{3}\right)$; and reticulocyte count $16 \cdot 8^{\circ}$. A peripheral blood film contained occasional spherocytes, and a marrow aspirate showed normoblastic hyperplasia. Bilirubin concentration was $48 \mu \mathrm{mol} / 1$ ( $2.8 \mathrm{mg} / 100 \mathrm{ml})$, ANF was absent, and similar investigations to those in case 1 showed no evidence of intracorpuscular abnormality or of intravascular haemolysis. The DAGT result was positive (table). Autologous erythrocyte survival was $14 \cdot 6$ days, with a spleen to liver ratio of $2 \cdot 8: 1$. She was begun on high-dose steroids $(60 \mathrm{mg}$ prednisolone daily), her clinical state initially improving, with a fall in the DAG' $\Gamma$ titre to 180 . The development of diabetes on a steroid dosage required to control haemolysis necessitated splenectomy. Steroids were then stopped completely. When last seen she was clinically well with a normal haemoglobin concentration and reticulocyte count, but the DAGT titre remained positive at $1 / 400$ (anti-IgG) and $1 / 64$ (anti-complement).

Family study-The results of antiglobulin testing, red-cell genotyping and HLA typing in cases 1 and 2 and of three entirely normal and apparently full sisters (cases 3-5) are shown in the table. Both sisters with AIHA had HLA antigens 1,8 , and 7 .

\section{Comment}

Experiments on New Zealand black mice have yielded strong evidence that AIHA can be hereditary. ${ }^{5}$ Though it is now recognised that autoimmune disease in man is often familial-for example, pernicious anaemia and thyroid disease-the paucity of reports of familial AIHA implies that its occurrence is likely to be coincidental. The finding of the sharing of common HLA antigens ( 1 and 8 ), shown to be increased in incidence in cases of AIHA, however argues for a genetic susceptibility to develop this disorder. Furthermore, the two oldest normal siblings (cases 3 and 4 ) did not possess such HLA antigens. Though the third normal sibling (case 5) had HLA antigens 1 and 8 , she had not reached the age at which cases 1 and 2 presented.

We hope that this report will stimulate further such documentation.

We thank Dr S H Davies and Professor R H Girdwood for permission to report on these patients under their care; Dr Jean Whitaker for co-operation in providing blood specimens; $\mathrm{Mr}$ George Willis and technical colleagues for serological testing; and Mrs E Scott for typing the report.

1 Seip, M, et al, Acta Paediatrica Scandinavica, 1969, 58, 275.

2 Pollock, J G, et al, British fournal of Haematology, 1970, 18, 171.

${ }^{3}$ Roth, P, et al, Schweizerische medizinische Wochenschrift, 1975, 105, 1584.

4 Da Costa, J A G, et al, fournal of Clinical Pathology, 1974, 27, 353.

5 Talal, N, and Steinberg, A D, Current Topics in Microbiology and Immunology, 1974, 64, 79.

(Accepted 1 February 1977)

Department of Haematology, Royal Infirmary, Edinburgh EH3 9YW F TOOLIS, MB, MRCP, senior registrar

A C PARKER, PHD, MRCP, lecturer

Regional Blood Transfusion Centre, Royal Infirmary, Edinburgh EH3 9YW

A WHITE, PHD, principal scientific officer

S URBANIAK, BSC, MRCP, consultant

Red-cell typing, leucocyte typing, and serological findings in five sisters

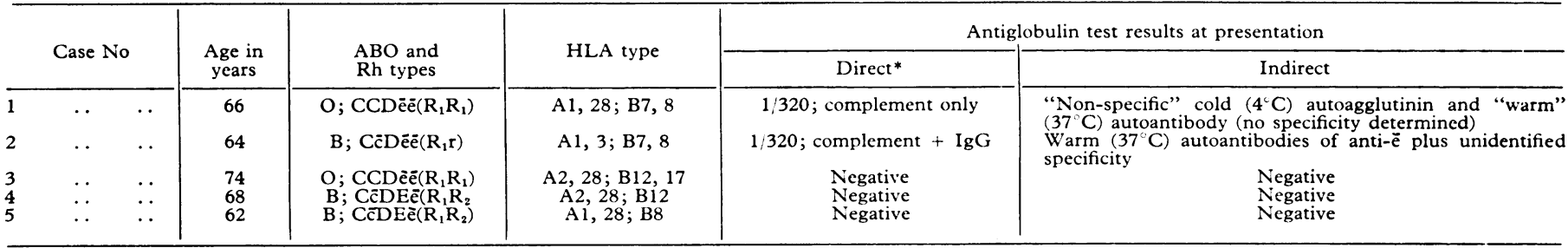

${ }^{*}$ Direct test performed with broad-spectrum reagent; when result positive, then serum also tested against monospecific anti-IgA, IgM, and IgG and C3. 